Key words: logarithmic mean temperature difference, heat exchanger, Nusselt number, nanofluids, overall heat transfer coefficient

\author{
R. DHARMALINGAM*, K.K. SIVAGNANAPRABHU ${ }^{* *}, J$. YOGARAJA*, \\ S. GUNASEKARAN", R. MOHAN ${ }^{* * *}$
}

\title{
EXPERIMENTAL INVESTIGATION OF HEAT TRANSFER CHARACTERISTICS OF NANOFLUID USING PARALLEL FLOW, COUNTER FLOW AND SHELL AND TUBE HEAT EXCHANGER
}

\begin{abstract}
Cooling is indispensable for maintaining the desired performance and reliability over a very huge variety of products like electronic devices, computer, automobiles, high power laser system etc. Apart from the heat load amplification and heat fluxes caused by many industrial products, cooling is one of the major technical challenges encountered by the industries like manufacturing sectors, transportation, microelectronics, etc. Normally water, ethylene glycol and oil are being used as the fluid to carry away the heat in these devices. The development of nanofluid generally shows a better heat transfer characteristics than the water. This research work summarizes the experimental study of the forced convective heat transfer and flow characteristics of a nanofluid consisting of water and $1 \% \mathrm{Al}_{2} \mathrm{O}_{3}$ (volume concentration) nanoparticle flowing in a parallel flow, counter flow and shell and tube heat exchanger under laminar flow conditions. The $\mathrm{Al}_{2} \mathrm{O}_{3}$ nanoparticles of about $50 \mathrm{~nm}$ diameter are used in this work. Three different mass flow rates have been selected and the experiments have been conducted and their results are reported. This result portrays that the overall heat transfer coefficient and dimensionless Nusselt number of nanofluid is slightly higher than that of the base liquid at same mass flow rate at same inlet temperature. From the experimental result it is clear that the overall heat transfer coefficient of the nanofluid increases with an increase in the mass flow rate. It shows that whenever mass flow rate increases, the overall heat transfer coefficient along with Nusselt number eventually increases irrespective of flow direction. It was also found that during the increase in mass flow rate LMTD value ultimately decreases irrespective of flow direction.

However, shell and tube heat exchanger provides better heat transfer characteristics than parallel and counter flow heat exchanger due to multi pass flow of nanofluid.
\end{abstract}

* Department of Mechanical Engineering, SNS College of Technology, Coimbatore, India,E-mails:dharmalingamsns@gmail.com,ajarmarine@gmail.com,guna03gm@gmail.com

** Department of Mechanical Engineering, RMK Engineering College, Chennai, India, E-mail:kksgnanam@gmail.com

*** Robert Bosch Engineering \& Business solutions pvt ltd, E-mail: rmohan575@gmail. com 
The overall heat transfer coefficient, Nusselt number and logarithmic mean temperature difference of the water and $\mathrm{Al}_{2} \mathrm{O}_{3}$ /water nanofluid are also studied and the results are plotted graphically.

\section{Introduction}

Conventional heat transfer fluids, such as mineral oil, synthetic oil, water and ethylene glycol, play an imperative role in many industrial sectors including air conditioning,power generation, transportation, chemical production and microelectronics. The performance of these fluids is often limited due to their thermo-physical properties. In lieu with the present industrial demands of process intensification and device miniaturization, development of high performance heat exchanging fluids is required. Owing to the high thermal conductivity of solid metals, lot of studies have been carried out in the past on the thermal behavior of suspensions of millimeter or micrometer sized particles, which showed some augmentation and practical problems such as poor suspension stability which lead to channel clogging which is particularly serious for the systems using mini and micro channel. As a result it is important to improve the heat transfer efficiency in telecommunication systems and manufacturing applications for the betterment of work efficiency.

\section{Literature survey}

More than $50 \%$ of the total electrical energy is consumed for thermal management in case of electronic cooling system [1]. Very high heat removal rate of the order of $2000 \mathrm{~W} / \mathrm{cm}^{2}$ is required in electronic systems like optical devices, X-rays and laser applications [2]. More than 50\% enhancement in heat transfer is achieved by using this colloidal mixture of nanoparticles with base fluids. However, researchers in the past decade tested less than $0.3 \%$ volume ratio of nanoparticles with base fluid. It is well known that micro-sized particles help to improve thermal conductivity and convective heat transfer of liquids when mixed with base fluids [3]. Meanwhile, the fluid path is disturbed and high pressure drop occurs due to sedimentation, excessive wear, and clogging due to micro-sized particles. These problems have been overcome, and improvements in thermal properties are achieved by using nanofluids. In nanofluids, the nanoparticles of $(1-100 \mathrm{~nm})$ and base fluid mixed thoroughly is identified by Choi in the year 1995 [4] at the Argonne National Laboratory. Many researchers focused on analyzing the nature of heat transfer and heat transfer characteristics of various nanofluids with different particle concentration and flow rates both experimentally and numerically. It was found that 
considerable enhancement in heat transfer characteristics under laminar and turbulent regime [5-15].

Upon considering the heat transfer characteristics of nanofluid using heat exchanger, Pantzalia M.N. et al. [16] investigated the performance characteristics of $4 \%$ volume concentration of $\mathrm{CuO} /$ water nanofluid using miniature plate heat exchanger with modulated surface. It was observed that greater enhancement of thermal conductivity and heat transfers along with more pressure drop. Pressure drop increases with volume concentration of nanoparticle increase. Mare T. et al. [17] studied the heat transfer characteristics of alumina mixed with water and aqueous solution of carbon nanotubes using two plate heat exchangers. The result shows that considerable improvement in convective heat transfer of about $50 \%$ for $\mathrm{CNT}$ and $42 \%$ for $\mathrm{Al}_{2} \mathrm{O}_{3}$ nanofluid when compared with water. Kwon et al. [18] tested $\mathrm{ZnO}$ and $\mathrm{Al}_{2} \mathrm{O}_{3}$ nanofluid in plate heat exchanger. The Reynold's number was maintained between 100 and 500 and the heat exchanger working temperature was within $20^{\circ}-40^{\circ} \mathrm{C}$. It was found that the heat transfer coefficient increased to $30 \%$ at $6 \%$ volume concentration of $\mathrm{Al}_{2} \mathrm{O}_{3}$ nanofluid. Chun B.H. et al. [19] experimented convective heat transfer coefficient of alumina nanoparticle and transformer oil using double pipe heat exchanger under laminar flow conditions. The addition of nanoparticle in the base fluid increases the average heat transfer coefficient. They stated that the heat transfer characteristics mainly depend on the nanoparticle size, shape and surface properties. Ulzie Rea et al. [20] found that the heat transfer coefficient of zirconia-water nanofluid increases up to $2 \%$ in the entrance and 3\% in the fully developed region at $1.32 \%$ volume concentration. Yulong Ding et al. [21] found the enhancement of heat transfer around $350 \%$ at $\mathrm{Re}=800$ while using $0.5 \mathrm{wt} \%$ of CNTs. The enhancement at an axial distance was found to be 110 times of tube diameter. Ahmad Ghozatloo et al. [22] analysed the heat transfer characteristics of graphene nanofluid in shell and tube heat exchanger. The result stated that the thermal conductivity at $25^{\circ} \mathrm{C}$ was increased by $15 \%, 29.2 \%$ and $12.6 \%$ at the concentration of $0.05,0.075$ and $0.1 \mathrm{wt} \%$, respectively. It was observed that $13.1 \%$ increase in convective heat transfer coefficient at 0.1 wt $\%$ graphene nanofluids when temperature increased from 25 to $38^{\circ} \mathrm{C}$. Rohit $\mathrm{S}$. et al. [23] studied the performance characteristics of $\mathrm{Al}_{2} \mathrm{O}_{3}$-water nanofluid using concentric tube heat exchanger. The experimental investigation shows that the overall heat transfer coefficient of $\mathrm{Al}_{2} \mathrm{O}_{3}$-water nanofluid was $16 \%$ higher than water.

Recent advances in nanotechnology have allowed development of a new category of fluids termed as nanofluids. Such fluids are diluted liquid suspensions of nanoparticles with atleast one of their principal dimensions less than $100 \mathrm{~nm}$. They have a bulk solids thermal conductivity of orders higher than the base fluids. From previous investigations, nanofluids have been found to 
possess enhanced thermo-physical properties such as thermal conductivity, thermal diffusivity and convective heat transfer coefficients compared to those of base fluids like oil or water. The potential advantage of properly engineered nanofluids includes higher thermal conductivities than that of predicted by currently available macroscopic models. Little penalty have been identified due to the increase in pressure drop and pipe wall abrasion experienced by suspensions of millimeter or micrometer particles. A number of experimental studies have been performed to investigate the transport properties of nanofluids in past decade. Most of these studies are on the effective thermal conductivity under macroscopically stationary conditions.

In present days, many researchers are focusing on $\mathrm{Al}_{2} \mathrm{O}_{3}$ nanofluids due to ease of manufacturing, preparation and availability factors. Some of the thermal properties of $\mathrm{Al}_{2} \mathrm{O}_{3}$ and water are compared in Table 1 .

Table 1

Thermal properties of water and $\mathrm{Al}_{2} \mathrm{O}_{3}$

\begin{tabular}{|c|c|c|c|}
\hline S.NO & Property & Water & $\mathrm{Al}_{2} \mathrm{O}_{3}$ \\
\hline 1. & $C, \mathrm{~J} / \mathrm{kg} \mathrm{K}$ & 4179 & 765 \\
\hline 2. & $\rho, \mathrm{kg} / \mathrm{m}^{3}$ & 997.1 & 3970 \\
\hline 3. & $k, \mathrm{~W} / \mathrm{mK}$ & 0.605 & 40 \\
\hline 4. & $\alpha, \mathrm{m}^{2} / \mathrm{s}$ & $1.45 \cdot 10^{-7}$ & $1.31 \cdot 10^{-5}$ \\
\hline
\end{tabular}

A heat exchanger may be defined as equipment which transfers the energy from hot fluid to cold fluid with maximum rate, minimum investment and running cost. Generally, heat exchangers are classified according to the flow arrangement and type of construction. The different types of heat exchangers are parallel flow, counter flow, cross flow and shell and tube heat exchanger.

\subsection{Preparation of the $\mathrm{Al}_{2} \mathrm{O}_{3}$ nanofluid}

Preparation of nanofluids is an important stage and nanofluids are prepared in a systematic and careful manner. A nanofluid with uniform particle dispersion is required and the same is used for measuring the thermo-physical properties of nanofluids. In this work, water is taken as the base fluid for preparation of $\mathrm{Al}_{2} \mathrm{O}_{3}$ nanofluids.

\subsection{The methodology of mixing of nanoparticles in the base liquid}

In this method, the nanoparticles are directly mixed in the base liquid and thoroughly mixed by using stirrer. Preparation of nanofluid by this method 
gives poor suspension stability because the nanoparticles settle down due to gravitation after a few minutes of nanofluid preparation. The rate of settlement depends on the type of nanoparticles, viscosity and density of the host fluids. Ultrasonicator was used for the stirring of nanofluids.

The maximum capacity of the ultrasonication in the machine is 1 liter. Thus 6 times ultrasonicated was done to prepare 6 liters of nanofluid. Ultrasonication process was carried out for 45 minutes so that the nanoparticles were completely dispersed in the water and ensured that they are not sedimented. The weight of the nanoparticles is calculated by the law of mixture.The calculated weight of the particle is weighted accurately by a $0.1 \mathrm{mg}$ weighing machine and it is ultrasonicated.

\subsection{Experimental setup and data reduction}

The experimental setup consisting parallel flow heat exchanger, counter flow heat exchanger and shell and tube heat exchanger is shown in Fig. 1 and it is a combined unit which is tested at different flow rates and different temperatures. Figure 2 represents the flow circuits used for the experimental study. It consists of two flow circuits. One circuit is the hot fluid flow and the other is the cold fluid flow. The tank on the left side is the hot tank and the tank on the right side is the cold tank. The hot tank is fitted with a heater inside so as to heat the water at different temperatures and to supply it to the heat exchangers. The tank on the right side is of normal water to which ice is added so as to lower the temperature of the cold water.



Fig. 1. Experimental setup 


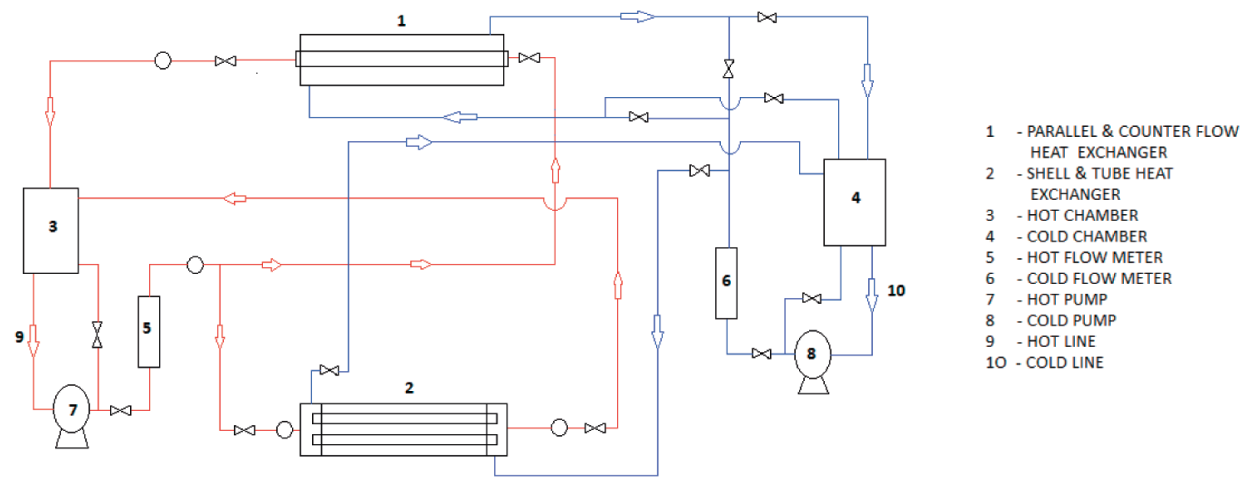

Fig. 2. Line diagram

Thus, cold water is passed through the heat exchangers, which leads to an increase in heat transfer between the hot water in the inner tube and the cold water which surrounds the tube. The heat exchangers shown in this experimental setup are parallel and counter flow heat exchanger and shell and tube heat exchanger. The hot fluid flow and cold fluid flow are controlled by flow meters of $0-1201 \mathrm{ph}$. The hot tank is provided with a heater and stirrer. The stirrer helps in maintaining the upper surface temperature and the lower surface temperature in constant state. The 2 tanks each are of the capacity of 6 liters. This ensures the piping networks have continuous flow of water. At a time a single heat exchanger is operated, which means flow to the other heat exchanger is controlled by control valves. The 15 control valves are used in this setup. The number of tubes used in shell and tube are 5 tubes of inner diameter $4 \mathrm{~mm}$ and of length $600 \mathrm{~mm}$. The inner diameter of the shell in shell and tube is $76.2 \mathrm{~mm}$ and the length is $600 \mathrm{~mm}$. The area of the heat exchangers is all the same. In parallel flow and counter flow heat exchanger the inner diameter of the outer tube is $80 \mathrm{~mm}$ and the length is $571.5 \mathrm{~mm}$. The inner tube of parallel \& counter flow heat exchanger is of diameter $21 \mathrm{~mm}$ and of length $571.5 \mathrm{~mm}$. The heat exchangers are of same area and are tested at same flow rates with same conditions. The table on which the experimental setup is fabricated is of size $900 \times 1800 \mathrm{~mm}$. The type of pipe used in the experimental setup is copper pipe of $19.05 \mathrm{~mm}$ inner diameter.

\subsection{Testing in the Heat Exchanger}

Initially, the experimental setup is verified for any defects by allowing the water to flow in the heat exchanger. Then, water is used as the fluid to exchange the heat. The inlet and outlet temperature of the hot and cold fluid is measured using $\mathrm{K}$ type thermocouple and the temperature indicator. The 
overall heat transfer coefficient, Nusselt number and LMTD for water have been calculated. Then the $\mathrm{Al}_{2} \mathrm{O}_{3}$ nanofluid is used as the fluid to transfer the heat. The inlet and outlet temperature of the hot and cold fluid is measured using the thermocouple and the temperature indicator. The overall heat transfer coefficient, Nusselt number and LMTD for $\mathrm{Al}_{2} \mathrm{O}_{3}$ nanofluid have been calculated.

The viscosity is calculated by Xuan and Roetzel [11] as follows:

$$
\frac{\mu_{n f}}{\mu_{w}}=\left(1.005+0.497 \varphi-0.1149 \varphi^{2}\right) .
$$

Thermal properties of nanofluid are calculated by Pak and Cho [24] as follows

$$
\begin{gathered}
\rho_{n f}=\varphi \rho_{p}+(1-\varphi) \rho_{w}, \\
\mu_{n f}=(1+2.5 \varphi) \mu_{w}, \\
\left(\rho c_{p}\right)_{n f}=\varphi\left(\rho c_{p}\right)_{p}+(1-\varphi)\left(\rho c_{p}\right)_{w}, \\
\frac{k_{n f}}{k_{w}}=(0.9692 \varphi+0.9508),
\end{gathered}
$$

where $\rho_{n f}$ is the density of the fluid, $\rho_{p}$ is the density of the nanoparticles, $\rho_{w}$ is the density of water, $\mu$ represents viscosity, $k$ stands for thermal conductivity, $c_{p}$ represents specific heat and subscripts $w$ and $p$ are the properties of water and nanoparticles. Here $\varphi$ is the volume concentration of the nanofluid.

The overall heat transfer coefficient is calculated using the formula

$$
Q=U A \Delta T_{m}
$$

where $\Delta T_{m}=$ Logarithmic Mean Temperature Difference (LMTD) in (K), $U=$ Overall Heat Transfer Coefficient $\left(\mathrm{W} / \mathrm{m}^{2} \mathrm{~K}\right), Q=$ Heat Transfer rate $(\mathrm{W})$. The heat transfer rate is calculated by the formula

$$
Q=m_{h} C_{p h} \Delta T,
$$

where $m_{h}=$ mass flow rate of the hot fluid, $C_{p h}=$ specific heat of the hot fluid, $\Delta T=$ temperature difference between inlet and outlet of the hot fluid. The Nusselt number is calculated from the correlation 


$$
\mathrm{Nu}=3.66+\frac{0.668 \frac{D}{L} \operatorname{Re}_{D} \operatorname{Pr}}{1+0.04\left(\frac{D}{L} \operatorname{Re}_{D} \operatorname{Pr}\right)^{0.67}}
$$

$\Delta T_{m}=$ Logarithmic Mean Temperature Difference (LMTD) is calculated from the relation,

$\Delta T_{m}=\left\{\left(T_{1}-t_{1}\right)-\left(T_{2}-t_{2}\right)\right\} /\left\{\ln \left[\left(T_{1}-t_{1}\right) /\left(T_{1}-t_{2}\right)\right]\right\}$ for parallel flow heat exchanger,

$\Delta T_{m}=\left\{\left(T_{1}-t_{2}\right)-\left(T_{2}-t_{1}\right)\right\} /\left\{\ln \left[\left(T_{1}-t_{2}\right) /\left(T_{2}-t_{1}\right)\right]\right\}$ for counter flow and shell and tube heat exchanger. $T_{1}=$ Hot fluid inlet temperature, $T_{2}=$ Hot fluid outlet temperature, $t_{1}=$ Cold fluid inlet temperature and $t_{2}=$ Cold fluid outlet temperature.

Using the above correlations, the overall heat transfer coefficient, Nusselt number and logarithmic mean temperature difference were calculated and tabulated in Table 2.

Table 2 .

Experimental results of $\mathrm{Al}_{2} \mathrm{O}_{3}$ /water nanofluid

\begin{tabular}{|c|c|c|c|c|c|c|}
\hline \multicolumn{7}{|c|}{ Parallel flow heat exchanger } \\
\hline \multicolumn{4}{|c|}{ Water } & \multicolumn{3}{|c|}{$\mathrm{Al}_{2} \mathrm{O}_{3} /$ water nanofluid } \\
\hline $\operatorname{Re}$ & $U$ & $\mathrm{Nu}$ & LMTD & $U$ & $\mathrm{Nu}$ & LMTD \\
\hline 600 & 116.17 & 13.84 & 13.83 & 130.72 & 14.9 & 16.1 \\
\hline 900 & 125.44 & 14.63 & 12.27 & 144.8 & 16.5 & 14.15 \\
\hline 1200 & 141.31 & 15.66 & 11.47 & 164.02 & 18.3 & 13.07 \\
\hline \multicolumn{7}{|c|}{ Counter flow heat exchanger } \\
\hline \multicolumn{4}{|c|}{ Water } & \multicolumn{3}{|c|}{$\mathrm{Al}_{2} \mathrm{O}_{3} /$ water nanofluid } \\
\hline $\operatorname{Re}$ & $U$ & $\mathrm{Nu}$ & LMTD & $U$ & $\mathrm{Nu}$ & LMTD \\
\hline 600 & 115.96 & 13.71 & 13.75 & 131.24 & 14.23 & 15.74 \\
\hline 900 & 127 & 14.57 & 12.45 & 144.6 & 15.98 & 14.15 \\
\hline 1200 & 140.9 & 15.62 & 11.37 & 163.98 & 17.63 & 12.9 \\
\hline \multicolumn{7}{|c|}{ Shell and tube heat exchanger } \\
\hline \multicolumn{4}{|c|}{ Water } & \multicolumn{3}{|c|}{$\mathrm{Al}_{2} \mathrm{O}_{3} /$ water nanofluid } \\
\hline $\operatorname{Re}$ & $U$ & $\mathrm{Nu}$ & LMTD & $U$ & $\mathrm{Nu}$ & LMTD \\
\hline 600 & 121.31 & 11.9 & 14.5 & 133.2 & 12.31 & 16.29 \\
\hline 900 & 132.82 & 14.03 & 13.2 & 147.5 & 15.24 & 14.9 \\
\hline 1200 & 142.02 & 14.69 & 11.97 & 166.4 & 16.23 & 13.2 \\
\hline
\end{tabular}




\subsection{Results and discussion}

The hot fluid inlet and outlet temperature, the temperature of cold fluid inlet and outlet at different mass flow rates have been measured using experimentation. Reynolds number $(\mathrm{Re})$ has been calculated based on mass flow rate and various parameters such as overall heat transfer coefficient $(U)$, Nusselt number $(\mathrm{Nu})$, and Logarithmic Mean Temperature Difference (LMTD) were calculated using equations.

Figure 3 shows the overall heat transfer coefficient $(U)$ of water and $\mathrm{Al}_{2} \mathrm{O}_{3}$ l water nanofluid with respect to Reynolds number $(\mathrm{Re})$ which varies from 600 to 1200 in parallel flow heat exchanger. The enhancement in overall heat transfer coefficient at Reynolds number 1200 is found to be $13.84 \%$ in parallel flow heat exchanger when compared with pure water. This is because the nanoparticles increase the thermal conductivity and a large energy exchange process resulting form the chaotic movement of the nanoparticles.

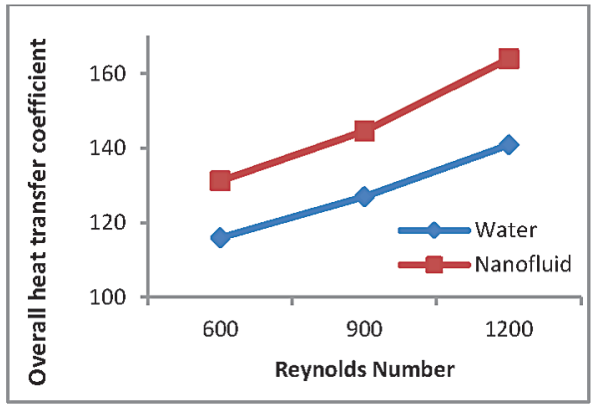

Fig. 3. $U$ vs. Re in parallel flow

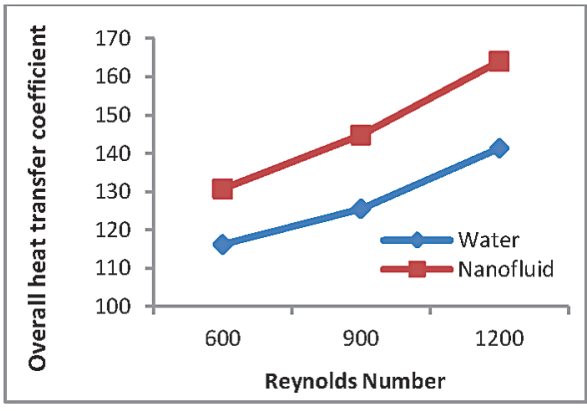

Fig. 4. $U$ vs. Re in counter flow

Figure 4 shows the enhancement in overall heat transfer coefficient is $14.07 \%$ in counter flow for same volume concentration of $\mathrm{Al}_{2} \mathrm{O}_{3}$ nanoparticles at Reynolds number 1200. It shows that better enhancement in heat transfer is obtainded in counter flow heat exchanger than parallel flow heat exchanger. Figure 5 shows $14.65 \%$ heat transfer enhancement in shell and tube heat exchanger at same $1 \%$ volume concentration of $\mathrm{Al}_{2} \mathrm{O}_{3}$ nanoparticles for Reynolds number 1200 . The variation in Nusselt number $(\mathrm{Nu})$ with respect to Reynolds number is shown in Fig. 6. It is found that the dimensionless Nusselt number increases with mass flow rate increase.

The average increase in Nusselt number of $\mathrm{Al}_{2} \mathrm{O}_{3}$ /water nanofluid is $14.4 \%$ in parallel flow heat exchanger when compared with pure water. In counter flow heat exchanger, the increase of Nusselt number value is $11.4 \%$ for same pipe length and diameter, and it is shown in Fig. 7. The increase in Nusselt number is $9.4 \%$ in shell and tube heat exchanger and it is shown in Fig. 8. 


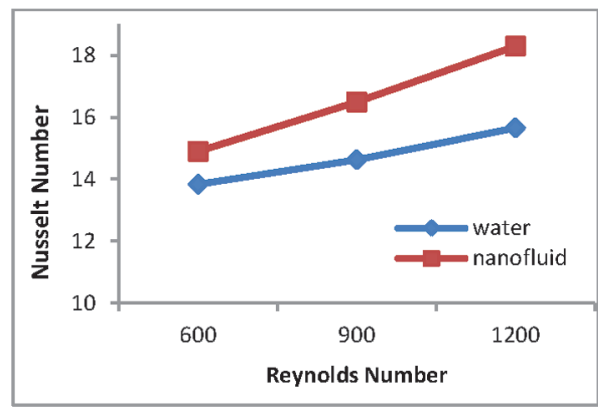

Fig. 5. $U$ vs. Re in shell and tube

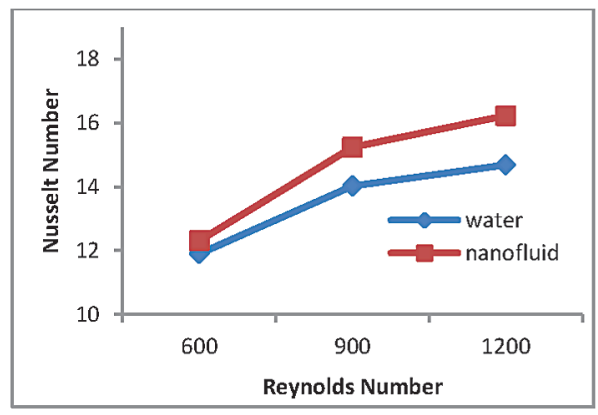

Fig. 7. Nu vs. Re in counter flow

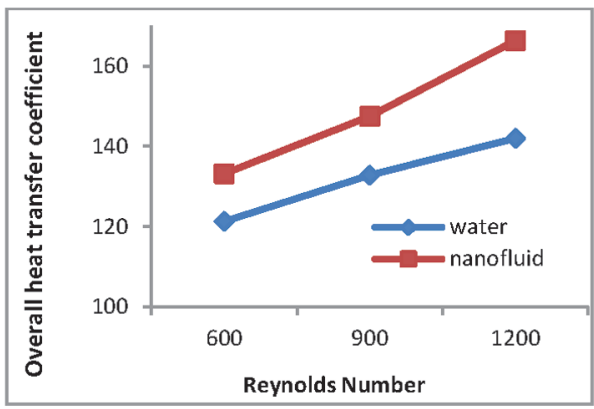

Fig. 6. Nu vs. Re in parallel flow

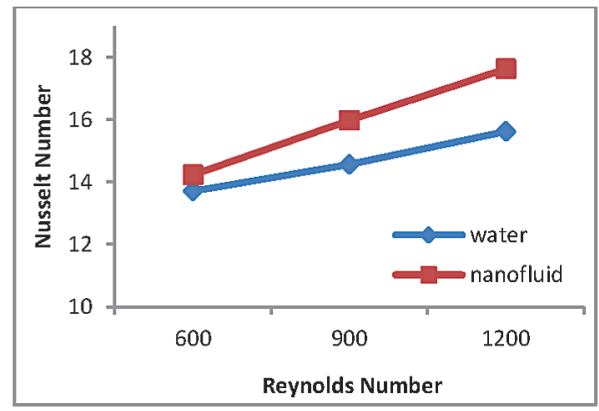

Fig. 8. Nu vs. Rein shell and tube

Figure 9 shows the variation in logarithmic mean temperature difference (LMTD) with respect to Reynolds number in parallel flow heat exchanger. There is $12.24 \%$ increase in LMTD at Reynolds number 1200 when compared with water in parallel flow heat exchanger. Variation in logarithmic mean temperature diffeerence (LMTD) with respect to Reynolds number in counter flow heat exchanger is shown in Fig. 10 and it claims 11.86\% when compared with water. Figure 11 represents an increase of 9.31\% LMTD value at Reynolds

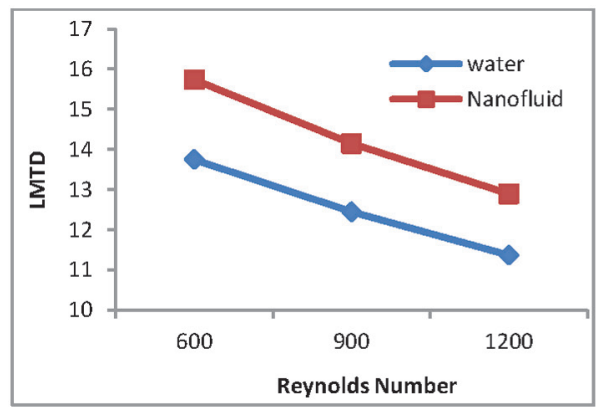

Fig. 9. LMTD vs. Re in parallel flow



Fig. 10. LMTD vs. Re in counter flow 
number 1200 is observed in shell and tube heat exchanger when compared with water. But the LMTD value decreases with Reynolds number increase. It shows LMTD is inversely proportional to mass flow rate at $1 \%$ volume concentration. But the maximun ratio between the LMTD of nanofluid and water, obtained for Reynolds number 600 in parallel flow heat exchanger, is 1.16 and minimum ratio is obtained in shell and tube heat exchanger at Reynolds number 1200 is 1.10 .

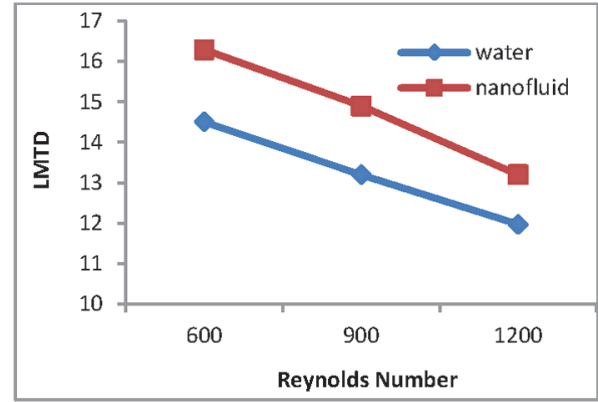

Fig. 11. LMTD vs. Re in shell and tube

Upon calculating heat transfer rate, maximum increase in heat transfer rate obtained is $22.6 \%$ for Reynolds number 1200 in shell and tube heat exchanger.

\section{Conclusion}

The convective heat transfer performance and the flow characteristics of $\mathrm{Al}_{2} \mathrm{O}_{3}$ nanofluid flowing in heat exchangers, namely parallel flow, counter flow and shell and tube heat exchangers, have been experimentally investigated. Experiments were carried out under laminar flow conditions. The effect of $\mathrm{Al}_{2} \mathrm{O}_{3}$ nanoparticle and the Reynolds number on the heat transfer performance and flow behavior of the nanofluid and water have been compared. It is concluded that for $\mathrm{Re}=1200$, the ratio of overall heat transfer coefficient of $\mathrm{Al}_{2} \mathrm{O}_{3}$ /water nanofluid with that of water is 1.161 for parallel flow, 1.146 for counter flow, 1.171 for shell and tube heat exchangers. It shows shell and tube exchanger provides more enhancements in heat transfer coefficient than the other two. The Nusselt number also increases for the $\mathrm{Al}_{2} \mathrm{O}_{3}$ /water nanofluid, which in turn will increase the convective heat transfer coefficient. The shell and tube heat exchanger provides maximum heat transfer at Reynolds number 1200. In future, different particle volume concentration for the same particle size can be prepared and mixed with the 
base fluid. The optimum level of volume concentration can be identified by using suitable optimization technique to avoid sedimentation and clogging in pipe lines.

\author{
Manuscript received by Editorial Board, May 17, 2015 \\ final version, October 27, 2015
}

\title{
REFERENCES
}

[1] Yang J., Chan K., Wu X.: Energy savings with energy-efficient HVAC systems in commercial buildings of Hong Kong. International Conference for Enhanced Building Operations, 2006, Vol. 7-5-2.

[2] Das S.K., Choi S.U.S., Yu W., Pradeep T.: Nanofluids - science and technology. John Wiley\& Sons, 2008.

[3] Maxwell J.C.: Treatise on electricity and magnetism. Oxford: Clarendon Press:1873.

[4] Choi S.U.S., Eastman J.A.: Enhancing thermal conductivity of fluids with nanoparticles, in developments and applications of Non-Newtonian flows. ASME International Mechanical Engineering Congress \& Exposition, 1995, Vol. 66, pp. 99-103.

[5] Godson L., Raja B., Mohan Lal D., Wongwises S.: Enhancement of heat transfer using nanofluids-An overview. Renewable and Sustainable Energy Reviews, 2010, Vol. 14, No. 2, pp. 629-641.

[6] Eapen J., Rusconi R., Piazza R., Yip S.: The classical nature of thermal conduction in nanofluids. Journal of heat transfer, 2010, Vol. 132, No. 10, pp. 102402-15.

[7] Das S.K., Putra N., Thiesen P., Roetzel W.: Temperature dependence of thermal conductivity enhancement for nanofluids. Journal of heat transfer, 2003, Vol. 125, No. 4, pp. 567-574.

[8] Jang S.P., Choi S.U.S.: Effects of various parameters on nanofluid thermal conductivity. Journal of heat transfer, 2007, Vol. 129, No. 5, pp. 617-623.

[9] Godson L., Deepak K., Enoch C., Jefferson B., Raja B.: Heat transfer characteristics of silver/ water nanofluids in a shell and tube heat exchanger.Archives of Civil and Mechanical Engineering, 2014, Vol. 14, No. 3, pp. 489-496.

[10] Drew D.A., Passman S.L.: Theory of multi component fluids, SpringerBerlin, 1999.

[11] Xuan.Y, Roetzel.W.: Conceptions for heat transfer correlation of nanofluids, International Journal of heat and mass transfer, 2000, Vol. 43, No. 19, pp. 3701-3707.

[12] Pak B.C, Cho I.Y.: Hydrodynamic and heat transfer study of dispersed fluids with sub-micron metallic oxide particles. Experimental heat transfer, 1998, Vol. 11, No. 2, pp. 151-170.

[13] Lee S., Choi S.U.S., Li S., Eastman, J.A.: Measuring thermal conduct conductivity of fluids containing oxide nanoparticles. Journal of Heat transfer, 1999, Vol. 121, No. 2, pp. 280-289.

[14] Attia H.A.: Heimenz flow through a porous medium of a Non-Newtonian Rivlin-Ericksen fluid with heat transfer. Tamkang Journal of Science and Engineering, 2009, Vol. 12, No. 3 , pp. 359-364.

[15] Kandasamy R., Muhaimin I., Azme B.K., Rozaini bin Roslan.: Unsteady Hiemenz flow of $\mathrm{Cu}$-nanofluid over a porous wedge in the presence of thermal stratification due to solar energy radiation: Lie group transformation. International Journal of Thermal Sciences, 2012, Vol. 65, pp. 196-205.

[16] Pantzalia M.N, Mouza A.A, Paras S.V.: Investigating the efficiency of nanofluid as coolants in plate heat exchangers (PHE). Chemical Engineering Science, 2009, Vol. 64, No. 14, pp. 3290-3300. 
[17] Mare T., Halelfadl S., Sow O., Estelle P., Duret S., Bazantay F.: Comparison of the thermal performances of two nanofluids at low temperature in a plate heat exchanger. Experimental Thermal and Fluid Science, 2011, Vol. 35, No. 8, pp. 1535-1543.

[18] Kwon Y.H., Kim D., Li C.G., Lee J.K., Hong D.S., Lee J.G., Lee S.H., Cho Y.H., Kim S.H.: Heat transfer and pressure drop characteristics of nanofluids in a plate heat exchanger. Journal of Nanoscience and Nanotechnology, 2011,Vol. 11, No. 7, pp. 5769-5774.

[19] Chun B.H., Kang H.U., Kim S.H.: Effect of Alumina nanoparticles in the fluid on heat transfer in double-pipe heat exchanger system. Korean Journal of Chemical Engineering, 2008, Vol. 25, No. 5, pp. 966-971.

[20] Rea U., Mckrell T., Lin-wen Hu, Buongiorno J.; Laminar convective heat transfer and viscous pressure loss of alumina-water and zirconia-water nanofluids. International Journal of Heat Mass Transfer, 2009, Vol. 52, No. 7, pp. 2042-2048.

[21] Ding Y., Alias H., Wen D., Williams R.A.: Heat Transfer of aqueous suspensions of carbon nanotubes (CNT nanofluids). International Journal of Heat Mass Transfer, 2006, Vol. 49, No. 1, pp. 240-250.

[22] Ghozatloo A., Rashidi A., Mojtabashariaty-Niassar.: Convective heat transfer enhancement of grapheme nanofluids in shell and tube heat exchanger, Experimental Thermal and Fluid Science, 2014, Vol. 53, pp. 136-141.

[23] Khedkar R.S., Sonawane S.S., Wasewar K.L.: Water to nanofluids heat exchanger in concentric tube heat exchanger: Experimental study, Procedia Engineering, 2013, Vol. 51, No. 1, pp. 318-323.

[24] Pak B.C., Cho I.Y.: Hydrodynamic and heat transfer study of dispersed fluids with sub-micron metallic oxide particles, Experimental heat transfer, 1998, Vol. 11, No. 2, pp. 151-170.

\section{Badanie eksperymentalne charakterystyk przewodzenia ciepla w nanopłynach w warunkach przepływu wspólprądowego i przeciwprądowego w płaszczowych i rurowych wymiennikach ciepla}

\section{Streszczenie}

Chłodzenie jest niezbędne dla właściwego funkcjonowania i niezawodności różnorodnych produktów, jak urządzenia elektroniczne, komputery, samochody, systemy laserowe wielkiej mocy, itp. W sytuacji wzrostu obciążenia cieplnego i strumieni ciepła wytwarzanych przez urządzenia przemysłowe, chłodzenie jest jednym z najważniejszych wyzwań występujących w różnych gałęziach przemysłu, transporcie, mikroelektronice, itp. Płynami, które zwykle są używane do odprowadzania ciepła z tych urządzeń są woda, glikol etylenowy i oleje. Nanopłyny, opracowane w ostatnim czasie, wykazują generalnie lepsze charakterystyki przewodnictwa cieplnego niż woda. Przedstawiona praca stanowi podsumowanie badań doświadczalnych nad wymuszonym, konwekcyjnym odprowadzaniem ciepła i charakterystykami przepływu nanopłynu składającego się z wody i cząsteczek $\mathrm{Al}_{2} \mathrm{O}_{3}$ (w 1\% stężeniu objętościowym) w warunkach laminarnego przepływu współprądowego i przeciwprądowego w płaszczowych i rurowych wymiennikach ciepła. W przedstawionych badaniach użyto cząstek $\mathrm{Al}_{2} \mathrm{O}_{3}$ o średnicy ok. $50 \mathrm{~nm}$. Wybrano trzy różne prędkości przepływu masy, opisano wyniki eksperymentów. Wyniki te wskazują, że całkowity współczynnik odprowadzania ciepła i bezwymiarowa liczba Nusselta nanopłynu są, przy tej samej prędkości przepływu masy i temperaturze na wlocie, nieznacznie wyższe, niż dla samego płynu bazowego. $Z$ wyników doświadczalnych wynika, że całkowity współczynnik odprowadzania ciepła wzrasta wraz z prędkością przepływu masy. Pokazano, że gdy wzrasta prędkość przepływu masy, całkowity współczynnik odprowadzania ciepła wraz z bezwymiarową liczbą Nusselta ostatecznie wzrastają, niezależnie od kierunku przepływu. 
Stwierdzono także, że ze wzrostem prędkości przepływu masy wartość LMTD (średniej logarytmicznej różnicy temperatur) ostatecznie maleje, niezależnie od kierunku przepływu.

Niemniej, płaszczowe i rurowe wymienniki ciepła zapewniają lepsze charakterystyki odprowadzania ciepła niż wymienniki z przepływem współprądowym i przeciwprądowym, co wynika z wielostrumieniowego przepływu nanopłynu. Badano także całkowity współczynnik odprowadzania ciepła, bezwymiarową liczbę Nusselta i średnią logarytmiczną różnicę temperatur dla wody i nanopłynu złożonego $\mathrm{z}$ wody i $\mathrm{Al}_{2} \mathrm{O}_{3}$, a wyniki przedstawiono w formie graficznej. 